\title{
OCCURRENCE OF ARBOREAL-CLIMBING GRAPSIDS AND OTHER BRACHYURANS IN TWO MANGROVE AREAS OF SOUTHERN LUZON, PHILIPPINES
}

\author{
JIMMY T. MASAGCA \\ Catanduanes State Colleges, Virac 4800, Catanduanes, The Philippines; \\ Pacific Island Institute for Pedagogy, Technology, Arts \& Sciences, Inc. (Pacifictech) \\ 82 A Constantino Street, Virac 4800, Catanduanes, Philippines; \\ De La Salle University-D, Cavite, Philippines)
}

Received 06 August 2010/Accepted 02 May 2011

\begin{abstract}
Despite the obvious importance to ecosystem functioning, the most prominent groups belonging to the Grapsidae are generally regarded as less studied in the Philippines. In this study, the occurrence of arboreal-climbing grapsids and other brachyurans associated with the mangals of Quezon and Catanduanes was considered including some aspects on climbing, burrowing and feeding behaviour of selected grapsids represented by Hemigrapsus, Pseudograpsus and Metopograpsus. The non-grapsoid taxa are represented by Varunidae (Ptychognathus), Portunidae (Charybdis, Portunus, Scylla, Thalamita); and Eriphiidae (Epixanthus). Metopograpsus latifrons (White 1847) [Grapsus] is an exclusive mangrove tree climber (EMTC), while Pseudograpsus elongatus (A. Milne Edwards 1873) is described here as occasional mangrove tree climber (OMTC). Hemigrapsus (Hemigrapsus) penicillatus (De Haan 1835) [Grapsus (Eriocheir)] is a non-mangrove arborealclimbing species (NTC) only seen on crevices of the mangrove areas. $P$. elongatus creates burrows most often than $M$. latifrons. Likewise, the study provides information on the presence of the portunid orange mud crab (Scylla olivacea); the green mud crab (S. paramamosain); the varunid (Ptychognathus altimana); and extremely abundant xanthiid crab, Epixanthus dentatus in the mangroves of Catanduanes but not in Pagbilao, Quezon.
\end{abstract}

Key words: Grapsid crabs, brachyurans, mangroves, Philippines

\section{INTRODUCTION}

The brachyurans are interesting to study in terms of their association with mangrove flora, behavior, feeding and ecology (Khan et al. 2005). This group makes up as much as $80 \%$ of the macro-faunal biomass in mangroves and densities can even reach to 80 to 90 sq. m. Reports attest that the mangrove forest constitutes the habitat

$\overline{\text { * Corresponding author : pacifictechjtm@yahoo.com }}$ 
with the richest diversity of land dwelling crabs (Hartnoll 1988, Fratini et al. 2005). It is also indicated that the most important functional role of mangrove crabs which received greater attention is their ability to process as much as $70 \%$ of the leaf litter (Leh \& Sasekumar 1985, Slim et al. 1997, Dahdouh-Guebas et al.1999, Ashton 2002). It was reported by Jones (1984) and Lee (1998) that brachyurans are important in the mangrove ecosystem structure and function. Members of family Grapsidae are possibly one of the most important components of the fauna of mangrove forests globally, in part because of their influence in nutrient cycling by feeding on litterfall (Salgado-Kent \& McGuinness 2010). Unfortunately, it appears that there is still a dearth of detailed published information on the structural components as to the occurrence of these grapsoidal families like Grapsidae and other brachyurans in the mangroves of the Philippines. There are few reports in this country that deal with the ways in which these crabs use the mangrove resources compared to other southeast Asian countries wherein numerous crab literature are available (Sivasothi 2000, Sivasothi et al. 1993, Tan \& Ng 1994, Ng \& Liu 1999, Leh \& Sasekumar 1985, Soemodihardjo \& Soerianegara 1989, Rahayu \& Davie 2002, Poovachiranon 1986, Lee \& Leung 1993, Lee 1998, Kwok \& Tang 2005). Except for some previous reports (McNae 1968, Banaag 1972, Zamora 1989a, Zamora 1989b, Dolar 1991, Dólar et al. 1991), there are scanty reports on occurrence, ecology and physiology of the mangrove-dwelling arboreal-climbing grapsid crabs in the Philippines.

This paper presents the occurrence of arboreal-climbing grapsid crabs and other brachyurans associated with the mangrove areas in Quezon and Catanduanes Island, Luzon (Philippines). Some insights on the dependence to mangrove trees as habitats, climbing skills and burrowing behavior of these grapsids are also noted.

\section{MATERIALS AND METHODS}

Crab specimens were handpicked and scooped using nets and locally made traps during daytime and at night time in two mangrove areas of southern Luzon, Philippines: (1) Palsabangon mangrove area, Pagbilao, Quezon; and (2) Agojo Inlet Mangrove Reserve Project and the Palnab-Pajo mangrove area in Catanduanes island. The collection sites include areas along rivers, creeks, inlets and the buffer zones or marginal strips of the coastline from June 2005 to February 2006. In addition nearby rivers, backshores and inside mangrove forests were also surveyed in May 2007 for these arboreal-climbing grapsid crabs. One female and several male specimens were obtained in each study area.

Measurements of the crab specimens were represented by maximum carapace width ( $m c w)$; carapace length (cal); body height (boh); and chelar palm height (cph). Ratios of $\mathrm{cal} / \mathrm{mcw}, \mathrm{boh} / \mathrm{mcw}$ and $\mathrm{cph} / \mathrm{mcw}$ were computed. All measurements are made with Vernier calipers and ratios are in two decimal places following $\mathrm{Ng}$ and Liu (1999) as used by Masagca (2009). Observations on the feeding ecology of the crabs under study were carried out each of the mangrove study areas modifying the methods of Gillikin (2000). In the mangrove areas covered, presence or absence of crab species were determined by visual inspection in $10 \mathrm{~m}$ diameter plots along a transect 
perpendicular to the coastline, covering the full width of the forest. The study investigated at least 10 plots along a 100 to $200 \mathrm{~m}$ long transect in the study areas.

\section{RESULTS AND DISCUSSION}

\section{Occurrence and some taxonomic diagnosis descriptions on the morphometry}

Table 1 presents arboreal-climbing mangrove grapsid crabs described in the present study, while Table 2 shows the other brachyurans (or non-grapsids) occurring in the areas under investigation. Based on the field surveys conducted in banks of the streams or rivers, backshores and inside mangrove forests, the families of brachyurans included in this report are the (1) Grapsidae, (2) Portunidae, (3) Varunidae and (4) Eriphiidae. As shown in the said tables these brachyurans include 3 genera (Metopograpsus, Pseudograpsus and Hemigrapsus) for family Grapsidae; a single genus (Ptychognathus) for Varunidae; 4 genera (Scylla, Thalamita, Portunus and Charybdis) for Portunidae and a single genus (Epixanthus) for Eriphiidae.

Table 1. Summary of the different taxa of grapsoid sesarmid crabs identified in selected mangrove areas in Quezon and Catanduanes.

\begin{tabular}{clll}
\hline Family & \multicolumn{1}{c}{ Genus } & \multicolumn{1}{c}{ Species } & Occurrence/Location \\
\hline Grapsidae & Hemigrapsus & Hemigrapsus penicillatus & Quezon \\
& Metopograpsus & Metopograpsus latifrons & Catanduanes \\
& Pseudograpsus & Pseudograpsus elongates & Quezon \\
\hline
\end{tabular}

Table 2. Summary of taxa of non-grapsoid sesarmid crabs obtained from different locations.

\begin{tabular}{clll}
\hline Family & \multicolumn{1}{c}{ Genus } & \multicolumn{1}{c}{ Species } & \multicolumn{1}{c}{ Occurrence/Location } \\
\hline Varunidae & Ptychognathus & Ptychognathus altimana & Catanduanes, Quezon \\
Portunidae & Charybdis & Charybdis affinis & Quezon, Catanduanes \\
& Portunus & Portunus pelagicus & Quezon \\
& Scylla & Scylla serrata & Quezon, Catanduanes \\
& Thalamita & Thalla olivacea & Quezon \\
Eriphiidae & Epixanthus & Epixanthus dentatus & Quezon, Catanduanes \\
\hline
\end{tabular}

Based on field surveys, the different arboreal-climbing grapsid crabs associated with the mangrove areas under study include the three genera: (1) Hemigrapsus Dana, 1851 (Hemigrapsus penicillatus), (2) Metopograpsus H. Milne Edwards, 1853 (Metopograpsus latifrons) and (3) Pseudograpsus H. Milne Edwards, 1837 (Pseudograpsus elongatus). These grapsid crabs were known to occur both in the lowland portions of streams, estuaries, and backshores of the. The grapsid M. latifrons (White 1847) [Grapsus] in Quezon and Catanduanes island was observed to be associated with the sesarmid crabs, Perisesarma bidens (De Haan 1835) and Neosarmatium smithii H. Milne Edwards, 1853 [Sesarma]. This means that these mangrove crabs occupy the same spots in the mangrove habitats that include feeding as shown in their climbing and burrowing behavior. 
The same observation that greater number of grapsid crabs occur in the banks of the stream and at the backshore of the mangrove rather than inside or within the forests of the 2 mangrove areas confirming the previous made by Tam and Wong (2000), showing a significant difference in occurrence or diversity of grapsoid sesarmids and other brachyurans.

The succeeding paragraphs present some taxonomic descriptions and morphometry of the arboreal climbing grapsids and other brachyurans.

\section{Metopograpsus H. Milne-Edwards, 1853 (GRAPSIDAE)}

$=$ Metopograpsus H. Milne Edwards, 1853 (type species Cancer messor Forskal, 1775, subsequent designation by Davie, 2002; gender masculine)

\section{Metopograpsus latifrons (White, 1847) [Grapsus]}

= Grapsus latifrons White, 1847 [nomen nudum]

= Metopograpsus maculatus H. Milne Edwards, 1853

$=$ Grapsus (Grapsus) dilatatus De Haan in Herklots, 1861 (nomen nudum)

= Grapsus (Grapsus) dilatatus De Man, 1879

= Metopograpsuspictus A. Milne-Edwards, 1867

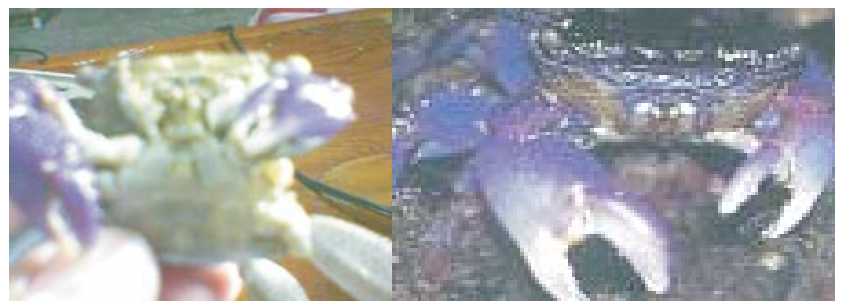

Figure 1. Metopograpsus latifrons from a Maqueda Channel mangrove area (Palnab-Pajo Mangrove) in Catanduanes Island

This arboreal-climbing grapsid has squarish carapace, slightly converging backwards; with $3^{\text {rd }}$ maxilliped not meeting in the middle line; and one tooth behind the antero-lateral one. Carapace of $M$. latifrons appears to be converging backwards.

This grapsid attacks the collector during several field works in Quezon and Catanduanes. This crab is conspicuously found in sluice gates of fish ponds in the mangrove area, prop roots of Rhizophora and tree trunks. As an arboreal - climbing grapsid crab, this opportunistic animal was observed to assume an inverted or downward position (facing the water) when found on trunks of mangrove trees. Some samples were also collected in crevices of trees during low tides. This grapsoid crab feeds on leaves, algae mollusks (Vannini et al. 1997) and crustaceans (Jones 1984). It is also stressed that in another species of the genus Metopograpsus, $M$. oceanicus is less dependent on the leaves of mangrove plants (Dahdouh-Guebas et al. 1999). In Singapore, 3 species (M. gracilipes, $M$. frontalis and $M$. latifrons) have been the subject of several reports.

Genus Pseudograpsus H. Milne Edwards, 1837

= Pseudograpsus H. Milne Edwards, 1837 (type species Grapsus penicilliger Latreille, 1817, subsequent designation by Holthuis, 1977; gender masculine) 
Brachyurans in two mangrove areas of Southern Luzon, Philippines - Jimmy T. Masagca

= Pachystomum Nauck, 1880 (type species Pachystomum philippinense Nauck, 1880, by monotypy; gender neuter)

\section{Pseudograpsus elongatus (A. Milne-Edwards, 1873) [Heterograpsus]}

= Pseudograpsus erythraeus Kossmann, 1877

Table 3 shows the mean values of morphometric data of grapsid crab Pseudograpsus elongates from the mangroves under study. Males tend to be larger in terms of body size as to maximum carapace width (mow) and body height (boh).

Table 3. Mean values (in mm) of the morphometry of P. elongatus from Catanduanes

\begin{tabular}{llllllll}
\hline $\begin{array}{l}\text { Sex of } \\
\text { crabs }\end{array}$ & mcw & cal & cal/mcw & Boh & boh/mcw & cph & cph/mcw \\
\hline Male & 32.95 & 37.23 & 1.13 & 18.62 & 0.56 & 14.82 & 0.45 \\
Female & 31.19 & 37.82 & 1.21 & 10.67 & 0.34 & 11.62 & 0.37 \\
\hline
\end{tabular}

Legend: $\mathrm{mcw}=$ maximum carapace width; $\mathrm{cal}=$ carapace length; $\mathrm{boh}=$ body height; $\mathrm{cph}=$ chelar palm height (all values are in $\mathrm{mm}$ ).

Female crab samples of $P$. elongatus, showed a mean $\mathrm{mcw}=31.19 \mathrm{~mm}$, while males $=32.95 \mathrm{~mm}$. In terms boh, females mean showed mean boh of $10.67 \mathrm{~mm}$ and males gave a mean boh of $18.62 \mathrm{~mm}$. Body form for females $(\mathrm{boh} / \mathrm{mcw}=$ $10.67 \mathrm{~mm} / 31.19 \mathrm{~mm}=0.34 \pm 0.01, \mathrm{~N}=2$ ), while for males $(\mathrm{boh} / \mathrm{mcw}=18.62$ $\mathrm{mm} / 32.95 \mathrm{~mm}=0.56 \pm 0.01, \mathrm{~N}=8$ ) the body form is relatively vaulted. Chelipeds equal and sexually dimorphic. Male chelae larger $(\mathrm{cph} / \mathrm{mcw}=14.82 \mathrm{~mm} / 32.95 \mathrm{~mm}=$ $0.45)$ and more strong than females $(\mathrm{cph} / \mathrm{mcw}=11.65 \mathrm{~mm} / 31.19 \mathrm{~mm}=0.37)$.

Identifying characters of $P$. elongatus are two distinct teeth behind the anterolateral one, carapace converging backwards. Carapace squarish, slightly converging backwards; $3^{\text {rd }}$ maxilliped not meeting in the middle line; legs and carapace not hairy, carapace slightly convex; two distinct teeth behind the antero-lateral one.

\section{Genus Hemigrapsus Dana, 1851}

= Hemigrapsus Dana, 1851 (type species Hemigrapsus crassimanus Dana, 1851, subsequent designation by Rathbun, 1918; gender masculine)

$=$ Lobograpsus A. Milne-Edwards, 1869 (type species Cyclograpsus crenulatus H. Milne Edwards, 1837, subsequent designation by Rathbun, 1918; gender masculine)

\section{Hemigrapsus penicillatus (De Haan, 1835) [Grapsus (Eriocheir)]}

= Brachynotus brevidigitatus Yokoya, 1928

Table 4. Mean values (in mm) of some of the morphometrics of H.penicillatus

\begin{tabular}{lccccc}
\hline Sex of crabs & mcw & boh & boh $/ \mathbf{m c w}$ & cph & cph/mcw \\
\hline Male & 28.72 & 17.02 & 0.59 & 9.39 & 0.33 \\
Female & 27.29 & 12.07 & 0.34 & 9.02 & 0.33 \\
\hline
\end{tabular}

Legend: $\mathrm{mcw}=$ maximum carapace width; $\mathrm{boh}=$ body height; $\mathrm{cph}=$ chelar palm height (all values are in $\mathrm{mm})$.

Table 4 shows the identity of the grapsid, H. penicillatus De Haan, 1858 from Catanduanes which was confirmed by Ms. Marivene Manuel from the PNM in Manila. 


\section{VARUNIDAE H. MILNE EDWARDS, 1853}

\section{Genus Ptychognathus Stimpson, 1858}

= Ptychognathus Stimpson, 1858 (type species Ptychognathus glaber Stimpson, 1858, by monotypy; gender masculine) [Opinion 85, Direction 37]

$=$ Coelochirus Nauck, 1880, (type species Coelochirus crinipes Nauck, 1880, by monotypy; gender masculine)

\section{Ptychognatbus altimanus Rathbun, 1914 [Varuna]}

Table 5 shows the summary of the mean values of selected morphometrics of P. altimanus. Males are bigger than females. Carapace pitted but glabrous, a little broader than long $(\mathrm{mcw} / \mathrm{cal}=39.54 / 36.08)$; lateral margin with two sharp teeth; legs fringed on the last 3 joints. Male chelipeds are larger $(\mathrm{cph} / \mathrm{mcw}=0.38)$ than the females $(\mathrm{cph} / \mathrm{mcw}=0.22)$.

Table 5. Mean values (in mm) of the some morphometrics of P. altimanus

\begin{tabular}{lccccccc}
\hline $\begin{array}{l}\text { Sex of } \\
\text { crabs }\end{array}$ & mcw & cal & $\begin{array}{c}\text { cal/mc } \\
\text { w }\end{array}$ & boh & boh/mcw & Cph & cph/mcw \\
\hline Male & 39.54 & 36.06 & 0.91 & 15.56 & 0.56 & 15.02 & 0.38 \\
Female & 33.09 & 32.56 & 0.98 & 15.36 & 0.34 & 7.37 & 0.22 \\
\hline
\end{tabular}

Legend: $\mathrm{mcw}=$ maximum carapace width; $\mathrm{cal}=$ carapace length; boh= body height; $\mathrm{cph}=$ chelar palm height (all values are in $\mathrm{mm}$ ).

Samples were collected near the canals connected to a small stream inundated during the high tides. This varunid crab is abundant in the backshore portions of the mangroves. Found in the back mangroves of Quezon and Catanduanes (near the rice paddies) and at the edges near the areas where freshwater streams are flowing. $\mathrm{Ng}$ et al. (2008) notes that Ptychognathus is being revised by N.K. Ng P.K.L. Ng. Several groups of species are now recognizable and new genera will be established for them.

PORTUNIDAE RAFINESQUE, 1815

Subfamily Portuninae Rafinesque, 1815

Genus Portunus Weber, 1795

Portunus(Pelagicus) pelagicus Linnaeus, 1758) [Cancer]

= Cancerpelagicus Forskal, 1775

$=$ Cancercedonulli Herbst, 1794

$=$ Portunus denticulatus Marion de Proce, 1822

$=$ Portunuspelagicus var. sinensis Shen, 1932

As shown in Table 6, males of $P$. pelagicus are bigger than females. Buccal frame rectangular; carapace much wider than long $(\mathrm{mcw} / \mathrm{cal}-116.57 / 48.44=2.41)$, bow fronted, and much serrate, drawn out into lateral spikes. Chelae strong but slender. Buccal frame rectangular, last pair of walking legs paddle-like; 9 antero-lateral spines. Samples of this portunid crab were obtained at the outer margins of the mangrove forest areas in Quezon and Catanduanes. The use of baited lift nets (local name= "bintol") allowed for the collection of this crabs. 
Brachyurans in two mangrove areas of Southern Luzon, Philippines - Jimmy T. Masagca

Table 6. Mean values (in mm) of the some morphometrics of P.pelagicus

\begin{tabular}{lccccccc}
\hline $\begin{array}{l}\text { Sex of } \\
\text { crabs }\end{array}$ & mcw & cal & cal/mcw & boh & boh/mcw & cph & cph/mcw \\
\hline Male & 116.57 & 48.44 & 0.42 & 25.73 & 0.22 & 17.78 & 0.152 \\
Female & 112.65 & 48.65 & 0.43 & 20.38 & 0.18 & 17.35 & 0.154 \\
\hline
\end{tabular}

Legend: $\mathrm{mcw}=$ maximum carapace width; $\mathrm{cal}=$ carapace length; boh= body height; $\mathrm{cph}=$ chelar palm heigh (all values are in $\mathrm{mm}$ ).

\section{Genus Scylla De Haan, 1833}

= Scylla De Haan, 1833 (type species Cancer serratus Forskal, 1775, subsequent designation by Rathbun, 1922; gender feminine)

\section{Scylla serrata (Forskal, 1775) [Cancer]}

= Achelous crassimanus MacLeay, 1838

= Scylla tranquebarica var. oceánica Dana, 1852

$=$ Lupa lobifrons $\mathrm{H}$. milne Edwards, 1834

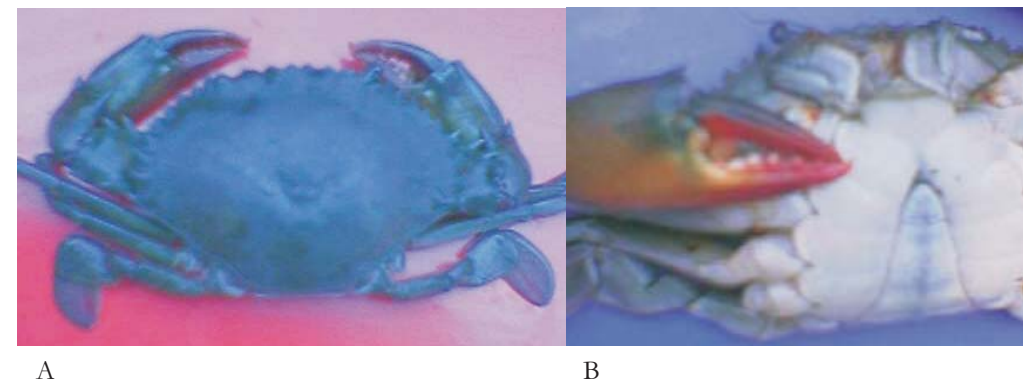

Figure 2. Scylla serrata (A, carapace) Pagbilao Quezon and Maqueda Channel Catanduanes.

As presented in Table 7, male samples of $S$. Serrata obtained from the study areas are smaller than the female samples. Samples obtained were heavy with moderately convex carapace $(\mathrm{mcw} / \mathrm{cal}-63.54 / 40.46=1.57)$, with 4 teeth; antero-lateral margin with 7 teeth, periopods/pleopods smooth, no hairs.

Table 7. Mean values (in mm) of the some morphometrics of S. serrata

\begin{tabular}{lllccc}
\hline Sex of crabs & mcw & boh & boh/mcw & cph & cph/mcw \\
\hline Male & 63.54 & 21.56 & 0.34 & 8.07 & 0.13 \\
Female & 67.85 & 23.45 & 0.35 & 9.23 & 0.14 \\
\hline
\end{tabular}

Legend: $\mathrm{mcw}=$ maximum carapace width; boh= body height; $\mathrm{cph}=$ chelar palm height (all values are in $\mathrm{mm}$ ).

\section{Scylla olivacea (Herbst, 1796) [Cancer]}

Summary data on selected morphometrics of $S$. olivacea are presented in Table 8. Ratios obtained for boh/mcw and $\mathrm{cph} / \mathrm{mcw}$ show almost the same values, which may indicate that sexual dimorphism is not that intense. 
BIOTROPIA Vol. 18 No. 2, 2011

Table 8. Mean values (in mm) of the some morphometrics of S. olivacea

\begin{tabular}{lllccc}
\hline Sex of crabs & mcw & boh & boh/mcw & cph & cph/mcw \\
\hline Male & 62.02 & 20.34 & 0.33 & 7.09 & 0.11 \\
Female & 63.52 & 21.57 & 0.34 & 7.26 & 0.12 \\
\hline
\end{tabular}

Legend: $\mathrm{mcw}=$ maximum carapace width; $\mathrm{boh}=$ body height; $\mathrm{cph}=$ chelar palm height (all values are in $\mathrm{mm}$ ).

\section{Genus Charybdis De Haan, 1833}

Charybdis (Charybdis) affinis Dana, 1852

$=$ ? Charybdis barneyi Gordon, 1931

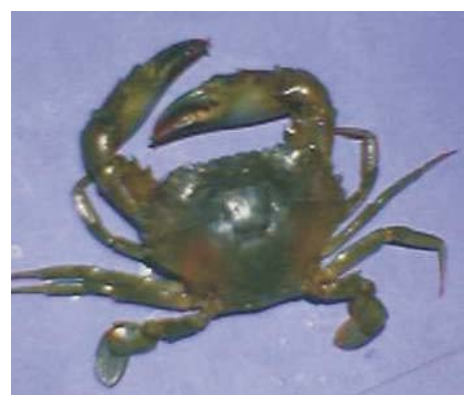

Figure 3. General view of Charybdis affinis from Quezon.

Carapace of C. affinis more or less hexagonal (mcw/cal 40.09/29.63=1.353), antero-lateral margins diverging backwards, fronto-lateral much less than maximum width, bow-shaped front cut into 6 teeth. Table 9 shows that the ratio of $\mathrm{cph} / \mathrm{mcw}$ for both male and female samples are almost the same. Ward (1941, cited by Ng et al. 2008) described C. philippinensis from Davao as: carapace is broader than long, bare and glossy, granulated under lens.

Table 9. Mean values (in $\mathrm{mm}$ ) of the some morphometrics of C.affinis

\begin{tabular}{lllccc}
\hline Sex of crabs & mcw & boh & boh/mcw & cph & cph/mcw \\
\hline Male & 43.34 & 16.8 & 0.39 & 17.78 & 0.41 \\
Female & 40.09 & 15.64 & 0.39 & 16.52 & 0.41 \\
\hline
\end{tabular}

Legend: $\mathrm{mcw}=$ maximum carapace width; $\mathrm{boh}=$ body height; $\mathrm{cph}=$ chelar palm height (all values are in $\mathrm{mm})$.

\section{Genus Thalamita Latreille, 1829}

= Thalamita Latreille, 1829 (type species Cancer adnete Herbst, 1803, by monotypy; gender feminine)

= Thalamonyx A. Milne Edwards, 1873 (type species Goniosoma danae A. Milne Edwards, 1869, subsequent designation by Rathbun, 1922; gender masculine)

\section{Thalamita crenata Ruppell, 1830 [Talamita, sic]}

As shown in Table 10, carapace of T. crenata (Figure 4) is much more or less hexagonal $(\mathrm{mcw}=50.63 \mathrm{~mm}$, cal $=32.02 \mathrm{~mm}$ ), but antero-lateral margins sub-parallel; fronto-orbital not much less than maximum carapace width; chelipeds strong 
$(c p h=11.35 \mathrm{~mm}$, male; $12.06 \mathrm{~mm}$, female); transverse ridges usually distinct. Carapace is rounded with five antero-lateral teeth.

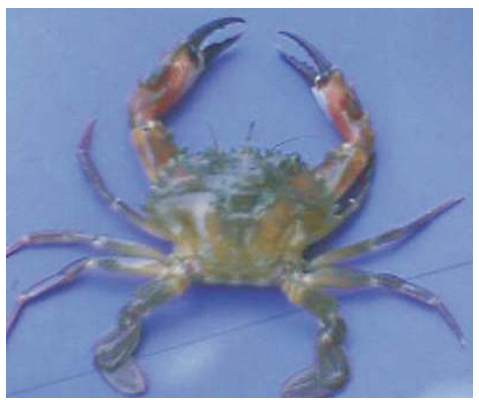

Figure 4. Thalamita crenata from Pagbilao, Quezon.

Table 10. Mean values $(\mathrm{in} \mathrm{mm}$ ) of the some morphometrics of T. crenato

\begin{tabular}{lccccccc}
\hline $\begin{array}{l}\text { Sex of } \\
\text { crabs }\end{array}$ & mcw & cal & cal/mcw & boh & boh/mcw & cph & cph/mcw \\
\hline Male & 50.63 & 47.01 & 0.93 & 17.93 & 0.35 & 11.34 & 0.22 \\
Female & 31.04 & 32.02 & 1.03 & 17.43 & 0.56 & 12.06 & 0.39 \\
\hline
\end{tabular}

Legend: $\mathrm{mcw}=$ maximum carapace width $\mathrm{cal}=$ carapace length; $\mathrm{boh}=$ body height; $\mathrm{cph}=\mathrm{chelar}$ palm height (all values are in $\mathrm{mm}$ )

\section{SUPERFAMILY ERIPHIOIDEA MACLEAY, 1838}

FAMILY ERIPHIIDAE MACLEAY, 1838

\section{Genus Epixanthus Heller, 1861}

= Epixanthus Heller, 1861 (type species Epixanthus kotschii Heller, 1861, by monotypy; gender masculine)

\section{Epixanthus dentatus (White, 1848) [Panopeus]}

= Epixanthus dilatatus De Man, 1879

= Panopeus acutidens Haswell, 1881

The mangrove crab, E. dentatus (Figure 5) displays two visible spines on the upper internal face of claw carpus; 5 big teeth on the antero-lateral carapace margins, carapace widely mottled. Celipeds are unequal (right larger than left). Table 11 shows that chelipeds of male samples (0.40) are larger compared to the female samples $(0.26)$

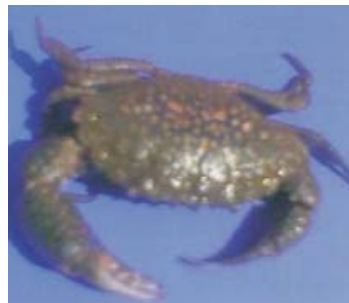

A

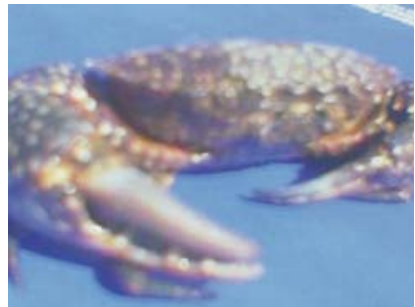

B

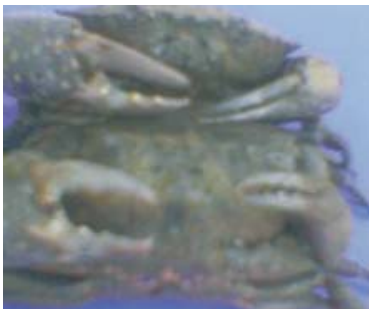

C

Figure 5. Epixanthus dentatus (carapace) from Palnab-Pajo Mangrove Area in Virac, Catanduanes (A), frontal view (B) and forcept-like claws (C). 
BIOTROPIA Vol. 18 No. 2, 2011

Table 11. Mean values (in mm) of the some morphometrics of E. dentatus

\begin{tabular}{llllllll}
\hline $\begin{array}{l}\text { Sex of } \\
\text { crabs }\end{array}$ & mcw & cal & cal/mcw & boh & boh/mcw & cph & cph/mcw \\
\hline Male & 45.02 & 32.41 & 0.72 & 19.32 & 0.43 & 18.21 & 0.40 \\
Female & 50.01 & 29.45 & 0.59 & 17.05 & 0.34 & 13.01 & 0.26 \\
\hline
\end{tabular}

Legend: $\mathrm{mcw}=$ maximum carapace width; $\mathrm{cal}=$ carapace length; $\mathrm{boh}=$ body height; $\mathrm{cph}=$ chelar palm height $(\mathrm{all}$ values are in $\mathrm{mm}$ ).

Samples of E. dentatus were obtained under drift woods, buried on the mud. The right claw of this crab is stout and consists of a special tooth which it uses to open gastropods. Plate 17B (Fig. 5) shows the forcept-like claw of the crab. This crab is omnivorous (Dahdouh-Guebas etal. 1999), but preys mostly on crabs (Cannicci et al. 2008).

\section{Arboreal-climbing, burrowing and feeding behavior of the grapsid crabs}

On the arboreal-climbing behavior, several individuals of the mangrove crabs, M. latifrons (White, 1847) were observed as exclusive tree-climber (EMTC) in mangrove canopies. This grapsid, invariably stays longer on the branches of mangrove trees with mostly upside down position. During the study, climbing height range of 50 grapsid crabs (in each study area) observed from $0.065 \mathrm{~m}$ to $2.35 \mathrm{~m}$ above the water lining. Majority of these grapsid crabs climb at the main trunks of Rhirophora and sometimes on the branch of Sonneratia when the tide is rising and when insects (e.g. spiders) are also found, since they are omnivorous feeders (Jones 1984). Although some M. latifrons are seen on the lateral branches, these are only happening when these grapsids were antagonized. It was observed that when $M$. latifrons are being caught by hand picking at the bottom of the trunk of the mangrove tree submerged in water, some of these crabs rushed to the upper portion of the trunk evading from the capturist. In Catanduanes, a greater number of $M$. latifrons occur in the mangrove areas studied supporting the high biomass and density report in Segera Anakan, Indonesia (Geist et al. 2011). This climbing behavior was not observed in the grapsid crabs of Quezon.

Another observation refers to the tendency of the grapsid, $M$. latifrons to climb in the fronds of Nypa fruticans when chased or antagonized while they are in the water. Individuals of this grapsid, M. latifrons (and also the sesarmid crab, Selatium elongatum) tend to escape or evade the researchers by climbing fast to the trees.

The other grapsid, P. elongatus, is known to be an occasional mangrove tree-climber (OMTC), while $H$. penicillatus is non-arboreal species (NAS) that was seen only in crevices of the mangrove areas.

On burrowing behavior, the grapsid $P$. elongatus also creates burrows and so with $M$. latifrons, but the former is more active compared to the latter. Burrowing activities have a pronounced effect on sediment properties, contributing immensely in rendering changes in the properties of mangrove sediments. As noted by Nagelkerken et al. (2008) changes in biochemical processes can be observed by enhancing the porosity and water flow through the sediment, assisting in flushing toxic substances. Crab burrows provide an efficient mechanism for exchanging water between the anoxic substrate and the overlying tidal water.

Jones (1984) described the feeding habits of mangrove crabs and divided into seven groups: herbivore, carnivore, omnivore, deposit feeder, omnivore/deposit 
feeder, specialized filterer, and filterer/omnivore. The grapsids $M$. latifrons, $P$. elongates and $N$. penicillatus are herbivores and omnivore/deposit feeders, eating mangrove litter and water plants. Nordhaus et al. (2011) described extensively the food preferences, diet and food consumption of grapsoid crabs in Indonesia. This will become an important reference for studying further the food and feeding habits of grapsids in the Philippines.

\section{CONCLUSIONS}

A total of 3 genera belonging to the family Grapsidae (Hemigrapsus, Psendograpsus and Metopograpsus) are reported here possessing tree-climbing abilities. Metopograpsus latifrons (White 1847) [Grapsus] is an exclusive mangrove tree climber (EMTC), while Pseudograpsus elongatus (A. Milne Edwards 1873) is described here as occasional mangrove tree climber (OMTC). Hemigrapsus (Hemigrapsus) penicillatus (De Haan, 1835) [Grapsus (Eriocheir)] is a non-mangrove arboreal-climbing species (NTC) only seen on crevices of the mangrove areas. The non-grapsoidal brachyurans are represented by 3 families [(Varunidae (Ptychognathus), Portunidae (Charybdis, Portunus, Scylla, Thalamita); and Eriphiidae (Epixanthus)]. To what extent this tree-climbing abilities of the said grapsid crabs in Quezon and Catanduanes relate to the feeding behaviour of the grapsid crabs reported in the present study awaits further studies. Likewise, food preference, diet and consumption of these grapsid crabs from the Philippines indicate future needs.

\section{ACKNOWLEDGEMENTS}

The author acknowledges with thanks to the De La Salle University-Dasmariñas, University Faculty Research Office (UFRO) for funding a research on the mangrove crabs. Profound thanks to Asst. Prof. Rico Masagca of DLSU-Manila and President \& CEO of Pacifictech, Mrs. Rose M. Gianan, Tersy M. Flores, Mrs. Margie M. Sabino, Mrs. Elsie M. Almonte, Yule, Mark, Kate and Marby Jean for their unending support in this work on mangrove brachyurans. The head of the Catanduanes State Colleges, Dr. Minerva Morales (SUC President III) is also greatly appreciated.

\section{REFERENCES}

\footnotetext{
Ashton EC. 2002. Mangrove sesarmid crabfeeding experiments in Peninsular Malaysia. Journal of Experimental Marine Biology and Ecology, 273: 97119.

Banaag JF. 1972. Vegetational composition and association in a mangrove forest ecosystem in Puerto Galera, Oriental Mindoro. Natural and Applied Science Bulletin, 29(1-2): 1-40

Cannicci S, Burrows D, Fratini S, Smith TJ, Offenberg J, Dahdouh-Guebas F. 2008. Faunal impact on vegetation structure and ecosystem function in mangrove forests: a review. Aquatic Botany, 89 (2): 186-200.
} 
BIOTROPIA Vol. 18 No. 2, 2011

Chen GC, Ye Y. 2010. Changes in properties of mangrove sediment due to foraging on Kandelia obovata leaves by crabs Parasersarma plicatum (Grapsidae: Sesarminae). Marine Ecology Progress Series.

Dahdouh-Guebas F, Giuggioli M, Oluoch A, Vannini A, Cannicci S. 1999. Feeding habits of non-ocypodid crabs from two mangrove forests in Kenya. Bulletin of Marine Science, 64: 291297.

Dolar MLL. 1991. A survey on the fish and crustacean fauna of the seagrass beds in North Bais Bay, Negros Oriental, Philippines, p. 367-377. In: Proceedings of the Regional Symposium on Living Resources in Coastal Areas. Quezon City: University of the Philippines marine Science Institute.

Dolar MLD, Alcala AC, Nuique J. 1991. A survey on the fish and crustaceans of the mangroves of the North Bais Bay, Philippines, p. 513-519. In: Alcala, A.C. (ed.) Proceedings of the Regional Symposium on Living Resources in Coastal Areas, University of the Philippines, Manila.

Fratini S, Vannini M, Cannicci S, Schubart CD. 2005. Tree-climbing mangrove crabs: a case of convergent evolution. Evolutionary Ecology Research, 7: 219-233.

Geist SJ, I Nordhaus, S Hinrichs. 2011. Occurrence of species-rich crab fauna in a human-impacted mangrove forest questions the application of community analysis as an environmental assessment tool. Estuarine, Coastal and Shelf Science, p.1-12.

Gillikin DP. 2000. Factors controlling the distribution of Kenyan brachyuran mangrove crabs: salinity tolerance and ecophysiology of two Kenyan Neosarmatium species. Unpublished MSc. Thesis, Vrije Universiteit Brussel, Belgium.

Hartnoll RG. 1988. Evolution, systematics and, geographical distribution. In: Biology of the Land Crabs (W.W. Burggren and B.R. McMahon, eds.), p. 654. Cambridge: Cambridge University Press.

Jones DA. 1984. Crabs of the mangal ecosystem. In: F. D. POR \& I. DOR (eds.), Hydrobiology of the Mangal: 89109. (Dr. W. Junk Publishers, The Hague).

Khan SA, Raffi SM, Lyla PS. 2005. Brachyuran crab diversity in natural (Pitchavaran) and artificially-developed mangroves (Vellar estuary). Current Science. 88(8): 1316-1324

Kwok PW .1995. The ecology of two sesarmine crabs, Perisesarma bidens (De Haan) and Parasesarma plicato (Latreille) at the Mai Po Marshes Nature Reserve, Hong Kong. Ph.D. thesis. University of Hong Kong.

Kwok WPW, Tang Wingsze .2005. An introduction to the common Sesarmine crabs of Hong kong. Issue No. 9. September. Retrieved on January 12, 2006. URL: http://www.hkbiodiversity.net/newsletters/ HKBOnewsletter9.pdf

Lee SY. 1998. Ecological role of grapsid crabs in mangrove ecosystems: a review. Marine and Freshwater Research, 49:335343.

Lee SY, Leung V. 1993. The brachyuran fauna of the Mai Po Marshes Nature Reserve and Deep Bay, Hong Kong. The Mangrove Ecosystem of Deep Bay and the Mai Po Marshes, Hong Kong. Proceedings of the International Workshop on the Mangrove Ecosystem of Deep Bay and the Mai Po Marshes, Hong Kong 1993, 57-82.

Leh CMU, Sasekumar A. 1985. The food of sesarmid crabs in Malaysian mangrove forests. Malayan Nature Journal, 39: 135145

Masagca JT. 2009. Feeding ecology of tree-climbing mangrove sesarmid crabs from Luzon, Philippines. BIOTROPIA (Southeast Asian Journal of Tropical Biology), 16 (1): 1-10.

McNae W .1968. The flora and fauna of mangrove swamps of the Indo-Pacific Region. Advances in Marine Biology, 6: 74-270.

Nagelkerken I, Blaber SJM, Bouillon S, Green P, Haywood M, Kirton LG, Meynecke J-O, Pawlik J, Penrose HM, Sasekumar A, Somerfield PJ .2008. The habitat function of mangroves for terrestrial and marine fauna: a review. Aquatic Botany, 89(2): 155-185.

Ng PKL, Guinot D, Davie PJF .2008. Systema Brachyurorum: Part I. An annotated checklist of extant Brachyuran crabs of the world. The Raffles Bulletin of Zoology, 17:1-286.

Ng PKL, Liu HC. 1999. The taxonomy of Sesarma tangi Rathbun, 1931 and S. stormi De Man, 1895 (Crustacea: Decapoda: Brachyura: Grapsidae: Sesarminae), with establishment of a new genus for $S$. stormi Zoological Studies, 38(2): 228-237. 
Brachyurans in two mangrove areas of Southern Luzon, Philippines - Jimmy T. Masagca

Nordhaus I, Salewski T, Jennerjahn TC. 2011. Food preferences of mangrove crabs related to leaf nitrogen compounds in the Segara Anakan Lagoon, Java, Indonesia. Journal of Sea Research, 65: 414-426.

Poovachiranon S .1986. The food of Chiromanthes bidens (De Haan, 1835) and C. maipoensis (Soh, 1978) (Decapoda: Sesarminae) from Hong Kong mangroves. In: The marine flora and fauna of Hong Kong and southern China (ed. B. Morton and C.K. Tseng), 727-35. Proceedings of the Second International Marine Biological Workshop: The Marine Flora and Fauna of Hong Kong and Southern China, Hong Kong, 2-24 April 1986. Hong Kong: Hong Kong University Press.

Rahayu DL, Davie PDF. 2002. Two new species and a new record of Perisesarma (Decapoda: Brachyura: Grapsidae: Sesarminae) from Indonesia. Crustaceana, 75: 597607.

Salgado-Kent C, McGuinness K. 2010. Spatial and temporal variation in relative numbers of grapsid crabs (Decapoda: Grapsidae) in northern Australian mangrove forests. Beagle, 26(1): 79-87.

Sivasothi N .2000. Niche preferences of tree-climbing crabs of Singaporre. Crustaceana, 73: 26-38.

Sivasothi N, Murphy DH, Ng PKL. 1993. Tree climbing and herbivory of crabs in the Singapore mangroves. In: Mangrove Fisheries and Connections. Proceedings of the ASEAN-Australian Marine Science Project: Living Coastal Resources Workshop1 (A. Sasekumar, ed.), p. 220237. Ipoh, Malaysia.

Skov MW, Vannini M, Shunula JP, Hartnoll RG, Cannicci S. 2002. Quantifying the density of mangrove crabs: Ocypodidae and Grapsidae. Marine Biology, 141: 725-732.

Slim FJ, Hemming MA, Ochieng C, Jannink NT, Cocheret de la Morinière E, van der Velde G. 1997. Leaf litter removal by the snail Terebralia palustris (Linnaeus) and sesarmid crabs in an East African mangrove forest (Gazi Bay, Kenya). Journal of Experimental Marine Biology and Ecology, 215: 3548.

Soemodihardjo S, Soerianegara I. 1989. The status of mangrove forests in Indonesia, p 73-114. In: Ishemat Soerianegara et al. (eds.), Proceedings of a Symposium on Mangrove Management: Its Ecological and Economic Considerations held in Bogor, Indonesia, August 9-11, 1988. BIOTROP Special Publication No. 37.

Tam FY, Wong YS. 2000. Hong Kong mangroves. City University of Hong Kong Press.

Tan CGS, Ng PKL. 1994. An annotated checklist of mangrove brachyuran crabs from Malaysia and Singapore. Hydrobiologia, 285: 75-84

Vannini M, Oluoch A, Ruwa RK. 1997. The tree-climbing crabs of Kenyan mangroves. In: Mangrove Ecosystems Studies in Latin America and Africa (B. Kjerfve, B.L. De Lacerda and E.S. Diop, eds.), p. 325338. UNESCO Technical Papers in Marine Sciences. New York: UNESCO.

Zamora PM. 1989a. Management policies and political awareness, p. 189-191. In: CD Field and M. Vanucci (eds.) Proceedings of the Symposium on New Perspectives in Research and management of Mangrove Ecosystems, 11-14, Nov. 1986, Sri Lanka.

Zamora PM. 1989b. Mangroves of the Philippines. BIOTROP special Publication (Bogor, Indonesia), 37: 43-65. 